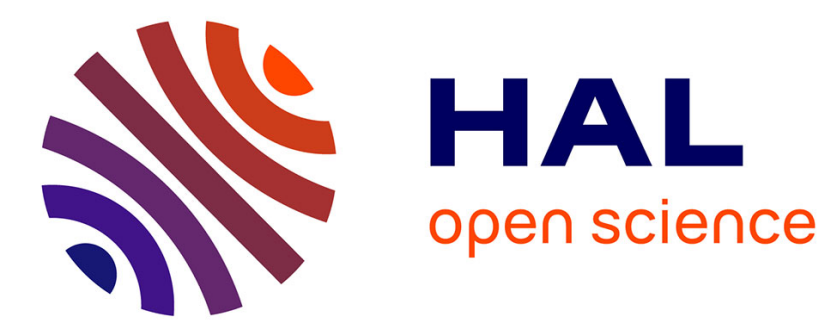

\title{
Crafting Ethics: The Dilemma of Almsgiving in Russian Orthodox Churches
}

Detelina Tocheva

\section{To cite this version:}

Detelina Tocheva. Crafting Ethics: The Dilemma of Almsgiving in Russian Orthodox Churches. Anthropological Quarterly, 2011, 84, pp.1011-1034. 10.1353/anq.2011.0060 . halshs-01666740

\section{HAL Id: halshs-01666740 \\ https://shs.hal.science/halshs-01666740}

Submitted on 18 Dec 2017

HAL is a multi-disciplinary open access archive for the deposit and dissemination of scientific research documents, whether they are published or not. The documents may come from teaching and research institutions in France or abroad, or from public or private research centers.
L'archive ouverte pluridisciplinaire HAL, est destinée au dépôt et à la diffusion de documents scientifiques de niveau recherche, publiés ou non, émanant des établissements d'enseignement et de recherche français ou étrangers, des laboratoires publics ou privés. 
Anthropological Quarterly, 2011, Vol. 84, No. 4, p. 1011-1034.

\title{
Crafting Ethics: The Dilemma of Almsgiving in Russian Orthodox Churches
}

\author{
Detelina Tocheva \\ Max Planck Institute for Social Anthropology, Halle/Saale, Germany
}

\begin{abstract}
With the liberalization of religious practices after the fall of the Soviet regime in Russia, almsgiving to beggars in Russian Orthodox churches has become one of the most widespread forms of Orthodox charity. However, the priests are faced with an ethical dilemma: should they be charitable with beggars or should they sanction those who do not live according to certain moral standards? This article examines how Orthodox priests interact with different groups of beggars and how they create ethical ways of acting. It proposes that contemporary Russian Orthodox ethics are multi-referential, anchored in historicity, relatedness, interaction, and creative reasoning. [Keywords: Russia, Russian Orthodoxy, Christianity, ethics, begging, almsgiving, value]
\end{abstract}

B egging appeared more openly in all urban settings of European Russia

soon after the dismantlement of the Soviet regime. The post-Soviet transformations also encouraged a particularly vivid revival of Russian Orthodoxy. Old churches reopened; new ones were erected. The surroundings of the Orthodox churches are nowadays typical places for begging. Church almsgiving has become one of the most ordinary expressions of Orthodox compassion in post-Soviet Russia. It is also a node of intense questions and tensions. The role of the Russian Orthodox Church (ROC) as a provider of social relief raises issues such as the interplay between religion and nationalism, the unequal position of different religious institutions in contemporary Russia, and diverging notions of charity, as Caldwell (2010) demonstrates. By focusing on almsgiving, I propose to look at this charitable practice as an arena constantly animated by ethical issues. In the eyes of Orthodox priests, the everyday dealings with often uncivil and smelly beggars are a trivial and charmless part of church life. But they are also, as those priests claim, the source of a vibrant ethical dilemma to which they are compelled to respond creatively: how to express Christian compassion and to refuse, at the same time, to support an unfit way of life? Through the concept of ethics, I examine how pragmatic solutions are crafted on an everyday basis and how frail equilibriums are reached that do not rule out uncertainty, hesitation, or contingency. This article is an exploration of the dynamics of the ethics of almsgiving. The priests themselves draw on several, sometimes contradictory, layers of the past that they emphasize and combine in individually and collectively meaningful ways: traditional notions of spontaneous uncontrolled almsgiving become colored by late 19th century ideas of 
modern target-oriented charity, and by 20th century Soviet notions of work. The historicity of these ethics not only informs my interpretation, it also serves as a resource consciously and selectively mobilized by the priests themselves. This diachronic aspect is intertwined with a synchronic aspect: the immediacy of practice, concrete ethical decisions, and interactions reveal how complex the priests' attitudes toward practical responses are. While priests usually approve of giving monetary handouts to passive beggars such as silent elderly women, they try to sanction younger ones who seem to be able-bodied, even though the priests usually refrain from expelling the latter totally. They have crafted ethics of simultaneous sanction and compassion that make it possible, at the same time, to "punish" the able-bodied beggars for their "bad" ways of life and to respond to their demand in the spirit of traditional Orthodox charity. In doing so, not only do the priests realize themselves as ethical persons, but they assume a responsibility toward beggars and society, what I call the society-centered nature of ethics.

Ethics in the sphere of religion are approached here as a dynamic area of practice and interaction, distinct from "morality." Or, as Douglas Rogers writes in his study of Old Believer ethics in a Russian provincial town, "the study of ethics should be distinguished from the study of morality and has interlocking social, cultural, and political dimensions" (2009:15). Ethics, for him, are best defined as a "field of practice." What can be grasped through individual "moral narratives" (Zigon 2010) is important, but such narratives should be analyzed in relation to practice,

interaction, and historicity.

Following Laidlaw (2002) and Rogers (2009), I use "ethics" in order to throw light upon practical processes, while "morality" and "morals" designate more circumscribed sets of rules and codes (e.g., "Soviet morals of work"). However, my approach differs from that proposed by Laidlaw inasmuch as my study of ethics is not exclusively an exploration of individual "ethical projects" whose ultimate goal is self-perfection (compare with Zigon 2008). Rather, I concentrate on how, while the Orthodox priests try to act with a concern for their self-realization as righteous persons, they are concerned also with the consequences that their decisions would have on others. The ethnography of the relational and interactive nature of almsgiving points out that the self is not the sole focus of ethics; these ethics are also society-centered.

There is a significant overlap between the above definition of "ethics" and the way in which some anthropologists of religion use "morality." Michael Lambek (2000) proposes a particularly suggestive approach to morality in the anthropology of religion. The concept of "reasoned moral practice" aims to "locate thought in the thick of immediate circumstances, in historicity, and in the constraints and opportunities of life" (2000: 318), thus sidestepping the opposition of static moral rules and dynamic practical action. However, Lambek' s “reasoned moral practice" leaves relatively open the question of its individual and collective aspects. In her study of Ukrainian evangelicals, Catherine Wanner argues for a recognition of multiple moralities at individual and collective levels:

So while morality indicates commitment to certain principles, it also embodies commitment to a group that helps uphold them through shared discourses and disciplining practices, which, in turn, reflect certain understandings of good and evil, of virtue and vice. By connecting moral understandings to faith-based communities, we see 
how particular articulations of morality intersect with those of other social groups to shape an individual' s commitment to various collectives and how these commitments change in tandem with particular socio-historical contexts. (2007:11-12)

This approach to the individual/collective nexus applies well to the Orthodox ethics of almsgiving.

But it would be incomplete if disconnected from the twofold role of historicity as historical background and consciously mobilized resource.

Studies of Christian and other denominations since the fall of the Soviet regime in 1991 document the selective but enduring social relevance of Soviet, pre-Soviet, and much older ideas, moral positions, and social configurations (e.g., Agadjanian and Rousselet 2010; Benovska-Sabkova et al. 2010; Luehrmann 2005; Paxson 2005; Rogers 2008, 2009; Wanner 2007; Zigon 2008, forthcoming). As Wanner and Steinberg (2008:17) write,

"The Soviet experience itself has nurtured understandings of good and evil, agency and destination, and authority and submission that are part of the cultural and social landscape today. Religious life remains entwined with these and still older legacies-to be embraced, adapted, or challenged." Rogers (2009) approaches these legacies as "an ethical repertoire" selectively mobilized in response to current demands. Their importance becomes relevant especially when the social actors themselves index certain practices and thoughts to specific historical periods or figures. This is precisely what Orthodox priests do and the reason why I pay special attention to some historical periods that my informants cited as frames of moral reference.

I combine this approach to ethics and morality in religion with a particular theory of value. Orthodox priests have crafted a resolution of the dilemma of almsgiving whereby they reaffirm the moral value of almsgiving by substituting some sorts of handouts (money), for others (food) (what Rogers [2009] calls "materials of ethics") and, thus, they believe they act responsibly vis-a-vis beggars and society at large. This is, I think, the most creative part of their ethical resolution and the one which is the most immediately rooted in society and action. When this happens, not only do they value different material objects in a variety of ways, but they realize value through the action, or rather interaction, of almsgiving. The priests' dilemma is indeed about how they act. This is where David Graeber' s theory of value is particularly relevant. He asks: "What if one did try to create a theory of value starting from the assumption that what is ultimately being evaluated are not things, but actions?" (Graeber 2001:49). For him, social value is realized in creative action, incorporated in some larger social totality, where "creative action...can never be separated from its concrete, material medium" (2001:54). This dynamic approach to the value of things and actions provides me with an optimal frame to think of the creative and interactive nature of the process in the course of which priests craft the ethics of almsgiving. Drawing on this, I propose the notion of the ethical valuation of things and actions in almsgiving as a critical, creative process that mobilizes, in direct and indirect ways, all the above-mentioned aspects of ethics: adherence to moral codes, creative reasoning and practice, historicity, and self-centered and society-centered orientations.

Recent studies of the religious revival of Orthodoxy in Russia focus on different types of participants in religious life: active participants (Agadjanian and Rousselet 2010, Naletova 2010, Sergazina 2006, Tarabukina 2000), occasionally involved people (Kollner forthcoming, 
Kormina 2010, Ładykowska forthcoming), or people who keep their distance from religion (Caldwell 2010). I take yet another approach by looking at the interactions between clerics and church beggars, who are usually considered to be non-religious persons.

The following sections focus on the ethical dilemma that priests face between expressing compassion towards some beggars and sanctioning others. I examine how the clerics define the beggars' degrees of deservingness and how different groups of beggars occupy the space inside and around the churches. I describe how the tension between giving alms and refusing is marked by different layers of the past, and how priests view this tension selectively as being marked by history. Finally, I show how clerics solve this dilemma by simultaneously stressing the value of what the beggars can do with the things given to them as handouts and the spiritual value of the act of almsgiving itself.

\section{The Dilemma}

Although Orthodox parish charity is almost never a formal endeavor, and in this respect it differs widely from better organized Christian charities in larger Russian cities (Caldwell 2004), the idea of helping the needy is deeply rooted in contemporary Russian Orthodoxy. Church almsgiving is now the most ordinary and widespread form of compassion in the vicinity of churches. The city where I did fieldwork in 2006-2007 is located about 50 kilometers away from St. Petersburg. 1 The setting is typical of the postSoviet Orthodox resurgence: an urban area where religious practices were very limited under late socialism; where popular forms of Orthodoxy preserved under socialism (outside of clerical control) are now labeled as ignorance and "paganism," and are being actively replaced by official doctrinal Russian Orthodoxy (for comparison, see Sibireva 2009a, 2009b). There are three parishes in the town. The main church of the first parish is Saint Peter, 2 with five priests and two deacons; it is centrally located at the head of the main pedestrian street, near the marketplace. The Church of the Mother of God, representing the second parish, is situated a five to ten minute walk from the central one. It has three priests and one deacon. In these two churches, beggars are almost always present as soon as they open. The third one, Saint John the Baptist, belongs to the third local parish which covers a former village that was incorporated into the town in the 1980s. This is the smallest church in which I worked, far from the city center and with only one priest as well as only occasional passers-by who beg. I draw my data also from less systematic observations in neighboring localities, as well as St. Petersburg and Moscow. The local parish communities are composed of a core group of clerics, church workers, the most committed parishioners, as well as less active and occasional churchgoers. The members, however, are not listed in any register and there is no official parish membership. The status of parishioners is conferred only orally and flexibly, by the clergy and by fellow parish members. The most active churchgoers are former and current factory workers, medical staff, teachers, and accountants; a few graduated from college and about one fourth are retired. Unlike the rural areas where elderly churchgoers are overrepresented (Sibireva 2009a), the urban churches in which I worked attract mostly middle-aged and younger active members and occasional visitors, as well as an equal number of women and men. 3 
Father 0leg is one of the most popular priests of the central church of the city, the Church of Saint Peter. A thin man in his 40 s, of rural origin, he is known as a humble person and a good priest, as well as one of the most appreciated confessors. With his wife, he takes care of their three childrena large family by Russian standards. Although his salary is modest, he refuses large donations offered to him personally by well-off churchgoers. His humbleness and piety inspire respect among the churchgoers.

Father 0leg started practicing Orthodoxy during the Soviet reform period known as Perestroika, in the second half of the 1980s. Like most churchgoers in the city, he did not learn about Orthodoxy from his parents who used to work in a state farm in the region of Tver. He acknowledges his relation to Orthodoxy through the faith of his parents: "My parents were believers, but never went to church. They did not speak of this [Orthodoxy]; there was no literature." 4 During the last years of the Soviet regime while carrying out his studies in agronomy, he started reading about religion and going to church. After graduation, he studied at the Orthodox seminary in St. Petersburg and subsequently became a priest. Like most contemporary urban churchgoers, he finds that, atheism and anti-religious campaigns aside, the Soviet system had a better moral basis than the post-Soviet period, which he refers to as "demokratsiia." Despite the fact that "We are free to go to church now" and that "many young people go to church, no more only babushkas," Father 0leg argued that Perestroika brought the end of good morality: "Perestroika was destruction," he thinks, for both industry (promyshlennost') and morality (nravstvennost'). According to him, before, everyone had a job and the police used to arrest all panhandlers and other idlers hanging around.

One can easily disagree with Father 0leg's enthusiastic presentation of the Soviet past. But Father Oleg' s nostalgic image of the Soviet moral atmosphere matters not as a true reconstruction; it is actually part of his deeply critical view of some aspects of I ife in Russia today. Rather than a romantic memory of the past, his evocation of Perestroika as destruction epitomizes the feeling of moral decline typically expressed by an overwhelming majority of Russians during the 1990s. The presence of beggars prominently figures as evidence of this decline and, more importantly, as a compelling call for action. In a conversation that we had inside the church, Father 0leg started commenting on the beggars:

I also face a dilemma. He begs. You have to give. But he is an idler, a sponger. There are disabled little old ladies. To them you can give. But the others, when we help them, we corrupt them $\cdots$ But we cannot push them out. The Lord will say to us: "Get out from the Celestial Kingdom!" ...He [the beggar] must pray for every kopek, not to use it for vodka. Morality is like this now, bad. Now there are these Uzbeks over here. 5 We get them used [to begging] and when they grow up,

they will still sit here.

Father 0leg' s dilemma is not one of a distant observer. How to act ethically vis-a-vis certain social characters is a pressing question for him, invoking the past, present, and future, as well as Orthodox and Soviet morals. In the same vein, more or less religiously engaged people say that, "in fact, when you give [to a beggar] you corrupt him." Thus, giving alms is seen as responsible for creating good and bad persons, for shaping selves. Surprisingly however, Father 0leg never expels the beggars, rather he lets them collect handouts.

The rector of the same central church, Saint Peter, is also a man in his 
late 40 s but, contrary to the other local priests, many of his close relatives are Orthodox clergymen. Additionally, he occupies the highest hierarchical position also acting as the rector of the higher level above the parish (blagochinie). He is the only one among the priests to drive a new gleaming black jeep with elegant leather interior, a nearly paradigmatic antithesis to Father Oleg' s tired Soviet Zhiguli. He was once quite harsh with an unknown beggar who asked for help. The man was unkempt and drunk. The rector became irritable, almost aggressive with him, and then went inside his office in the church. After a minute, the rector sent a young deacon out with a small package of food for the man. Although the man hoped to receive some money, as he told me, he was happy with the food he got. Neither the beggar nor the church workers sought to establish a closer relationship. Able-bodied beggars are an everyday pragmatic problem that continuously raises the same dilemma: should they be blamed and expelled, or should they be offered support? The ways in which solutions are crafted show the priests' twofold preoccupation: about their own realization as moral persons who "have to give," as Father Oleg had it, and about the socially consequential effects of almsgiving. In fact, acting righteously is an unstable construct that varies in interaction with differentiated groups of beggars and according to the subjective views of different priests.

\section{Characters and Spaces}

In post-Soviet Russia, begging is often linked to extreme urban poverty, social marginalization (Tikhonova 2003, Yates 2004), and homelessness (Hojdestrand 2005, Stephenson 1996). Kudriavtseva (2001) insists that individual beggars in Russian cities are not necessarily needy persons; some ingeniously represent socially legitimate characters like a retired woman, the church poor, a single mother, a sick old woman, or a holy fool (a typical figure of the Russian Orthodox tradition). Some researchers stress the coping strategies, the processes of stratification within groups of beggars with their internal rules and how they challenge the state order.6 I will not, however, go on to ask if these displays are based on "real" poverty and suffering, for a calculated demand for compassion does not exclude real need.

To describe the beggars' behavior, I use two general categories: active and passive beggars. The passive beggars are mainly old women who sit or stand at the entrance to the yard of the Saint Peter church or in the vicinity of the Church of the Mother of God, and are usually mute and immobile, silently addressing a demand to the visitors. I have never heard clergymen criticizing this type of beggar; rather the clerics point them out as exemplary recipients of handouts. These "little old ladies" (starushki), as clerics and believers affectionately call them, never cause trouble. They are seen as good poor, whose old bodies, quiet resignation, and passive attitudes legitimize their presence and expectation to receive help. For Kudriavtseva (2001), such women play the character of a retired woman (pensionerka): a woman deserving respect. Their distance from the entrance and their silent presence are not the only factors determining the clergymen's sympathy. From discussions with priests it comes out that behind the acceptance of "little old ladies" lies the assumption that they have worked all their life and that the miserable pensions Russia offers to retired people make it impossible for them to survive. They are 
part of those considered in Russian society to be the deserving poor on the implicit grounds that their social identity fits the dominant categories of the Soviet and post-Soviet models of social welfare (Yates 2004:233). Invalids, veterans, mothers of large families, or simply elderly persons, who worked when they were able-bodied but currently face poverty, are usually considered to be deserving.

Conversely, when the clergy and members of the core community discuss and criticize the practice of begging, they have a particular target: the active, mostly young and middle-aged beggars who appear to them as potential workers whose deservingness is constantly in question. They can be called "active beggars" and are often the most eye-catching. They are neither completely expelled nor openly accepted; their right to continue begging is a matter of permanent reflection and day-to-day arrangements by the clergy. They are the ones who raise acute ethical dilemmas for local priests. They stand next to the entrance of the two main churches mentioned above, Saint Peter and the Mother of God, or in the yard of the Saint Peter church. They move, talk to the visitors, and try by all means to collect coins. Often adult men, homeless and obviously alcoholic, stand next to the door. There are also groups of children accompanied by one or two women of Gypsy origin, who are the most mobile. 7 These are people who remain loyal to the same church, at least for some time. There are individual beggars too, most often Russian men, who go straight into the church and address a priest or a church worker for money. Only this kind of beggar comes to the third parish, the church of Saint John the Baptist. These individual passers-by are not begging regularly in one church; after having come once, they never come back to the same place. Only the active beggars arouse interest, even resentment; only they constitute, what the churchmen consider, a problem to be solved.

The local priests only allow begging outside the church. This unstated rule is often broken at the Church of the Mother of God. A group of three young locals, one girl in her late teens and two younger boys, one 14 and the other 16 years old, usually stand close to the door. Since this church has no yard, people come in directly from the street. In this configuration, the group stands close to the main entrance in order to attract the attention of visitors. This is also where two other people usually stand, a middle-aged woman and a man in his 40 s who is often drunk. The latter two beg silently most of the time and remain immobile. The group of young ones is, on the contrary, far more active. They speak to the visitors, approach them for money and food, run back and forth in the vestibules and sometimes inside the church, and joke and quarrel with one another. The girl and boy of 14 are siblings. They live with their parents, but nevertheless resemble "street children" in urban Russia-they lack parental control, use drugs, and live in poverty (Stephenson 2001). The girl is often drunk, her brother sniffs glue (the drug of the poor), and the other boy is frequently drunk as well. A former church worker had tried to convince the young panhandlers to go to the town' $s$ residential school but her attempts proved unsuccessful. 9 No one else tried to "normalize" them or to contact their parents; the status quo was tolerated. Clerics and church workers consider these young persons incapable of change because "this is how they are, too used to live as they do." This small teenage group has already helped with some renovation work in the half-ruined buildings situated behind the church. For example, the boy of 16 helped clean up after a wedding in the Saint Peter church and received 100 rubles. This is 
the kind of work that the two parishes use them for from time to time. But for the church insiders, this does not seem sufficient in order to say that they really work. 10

\section{Ethics as Interaction}

These young beggars are often discussed among clerics and members of the core community of the Church of the Mother of God-about a dozen people who are the most active, cleaning up, working in the church shop, and singing in the choir. In most matters, this core community strictly follows the rector, a charismatic elderly priest born in Soviet Ukraine but who has served all his life in this town. Like Father Oleg, he is known for his humbleness and self-restraint. This rector made a special decision concerning the small group of panhandlers. In March 2007, a placard appeared on the external door of the church:

Brothers and sisters!

Do not give alms in the entrance! Only on the church porch! Blessing of Father the Rector A similar placard was posted on the internal door. There are several explanations about what gave rise to this prohibition: one of the boys stole money from the shop cash box; parishioners complained about the smell of alcohol and glue; the young group quarreled in the church during a funeral ceremony. The two boys and the girl confirmed the latter story in their own half-joking, half-guilty way. After the placards were posted, the new formal rule was disregarded sometimes, especially during important feasts, when numerous visitors came. The placards of the elderly rector formalized the space by attempting to keep the "bad" beggars at a certain distance while letting them be a part of church life.

Although the rector of the Church of the Mother of God does not give alms and urges churchgoers to avoid doing so inside the church, his relationship with the beggars is not pure repressive control. The two siblings mentioned above had an elder brother who did not beg. One morning people found him frozen to death in the street. His siblings were deeply affected by the event, while the church workers assumed that he must have been drunk. Despite the accusatory comments, the priest performed a funeral (otpevanie) free of charge, demonstrating in this way that the parish was related to its panhandlers and to their families.

Despite their loyalty to the rector, the most engaged church workers and churchgoers also have individual opinions about almsgiving. The director of the choir of the Church of the Mother of God is a man in his early 40s. He aspired to become a priest but could not because he married a divorced woman. He is one of the prominent characters of this parish, known for his generosity and kindness. Like others, when commenting on beggars, he told me: "We need them more than they need us.

Giving to them is a path toward salvation, because God sends them to us." However, one should not interpret his words as revealing a kind of utilitarian compassion convertible into salvation, for, as he explained to me, the way to salvation cannot be reduced to accomplishing acts of almsgiving. While other churchgoers also insist on charity, they too stress criticism by underlining the beggars' laziness and sinful way of life. A woman in her 50s, who works as a ticket seller at the train station and sings in the church choir, provides a good example of how the two points of view are combined. She told me, like many other parishioners and external people did, 
that "begging is a business now," by which she meant it was a calculated demand for compassion. She added, however, that "for the sake of your salvation, if you have a spare ruble, you better give it."

The rector of the smallest parish, Saint John the Baptist, is the most radical in managing the problem of the active beggars, and is known for being the most demanding and hard with his parishioners. A man in his early 40 s, he is the only priest of the parish. He left his native Soviet Ukraine at the end of the 1980s to study in what was then Leningrad. Unlike most of the other local priests, he says that he was already a believer in his childhood. Since the church is located far away from the central area and is open only on the weekends and whenever there is a feast during the work-week, this priest does not face the problem of begging in his church on a daily basis. These limitations of access explain to a great degree why the beggars are more attracted by the two central churches. When I asked the priest why there were no beggars at the entrance of his church, he said: "I forbade it. They beg for vodka." He spoke of what happened when people, especially middle-aged men, knocked on the door of his house, just behind the church, asking for help:

They approach me and they approach all the other priests. "Give me food," they say. I give them some. "Give me money to buy a ticket." But I know that they beg for vodka $\cdots$ You open the door and a man (muzhik) stands there, strong and healthy. I tell him

"I will give you money if you work here. There is a lot of snow. Remove it." He refuses.

This priest is critical of contemporary beggars and conceives of monetary alms only as a reward for beggars' commitment to work. He blames the beggars for their absence of faith; yet, he maintains an idealized view of the "good" beggars of the pre-Soviet and Soviet past. According to him, in his childhood, the poor and the disabled accepted everything; they prayed and said "in the name of Christ" (Radi Khrista), whereas now they ask for money only to buy vodka. Pre-revolutionary and Soviet church beggars were, to his mind, good and faithful. As evidence, he showed me a recently published book about Orthodoxy, in which an old photograph taken before the revolution showed two beggars: a man and a young boy.

"This is a blind man and an orphan child, he explained. They begged together and supported each other." For him, pre-revolutionary and Soviet pasts are different but equally pious, and in this respect they are in a clear opposition to the lack of spirituality in contemporary begging and almsgiving:

"Now, there is one who throws out money and another one who takes it." In other conversations, he often deplored fading faith in general. He criticizes those newly rich who invite him to bless their new houses and who take this act as magical protection, and those people who wish to get married in his church without cultivating the Orthodox faith in their heart. For him, beggars are just one part of all those faithless Russians who use priests to their own ends.

Another time, he stressed that "in the Acts of the Apostles, Christ said that it is better to give than to beg." This is a slightly modified quotation of a sentence that one finds in the chapter "Property" in The Basis of the Social Concept, the most prominent recent theological document of the ROC adopted in 2000. However, the paragraph to which it belongs does not mention begging:

An owner of a considerable wealth does not sin if he uses it in accordance with the will of God to Whom everything belongs and with 
the law of love; for the joy and fullness of life lie not in acquirement and possession but in giving and sacrifice. St. Paul calls people

"to remember the words of the Lord Jesus, how he said, "It is more blessed to give than to receive' " (Acts 20:35). (Russian Orthodox Church 2000)

What is meant here is that the rich should not accumulate wealth but should share it through "giving and sacrifice." In fact, the priest substituted

"to beg" for the original "to receive" in the quotation from Saint Paul, altering the meaning in a way that supported his critical view of begging.

This substitution of the verb "to beg" was certainly not conscious and intended; rather this slipping testifies to the frequent subjective usages of authoritative references by parish priests in support of their opinions and decisions, typically voiced in the form of assertions starting with: "As the Holy Fathers said..."

Although the positions of the individual priests are multi-referential morally and historically-and thus they subjectively emphasize one or another code, period, or figure-theology, traditional practice, Soviet morals, and post-Soviet discourses appear as shared frames of moral reference. Below, I review some recent and earlier theological views about begging and almsgiving, and historical moments that marked Orthodoxy' s relationship to begging, and then I turn to Soviet attitudes toward begging.

In these cases, work appears as a structuring ethical category, differently involved in varying historical moral models of piety and deservingness.

\section{Orthodox Almsgiving}

Russian Orthodox theology has for a long time emphasized two spheres of righteous Christian Iife: charity and labor. Fedotov (1966), a well known Russian Orthodox theologian of the first half of the 20th century, analyzed a medieval collection of anonymous essays drawing on sermons of early Christian theologians that served as a guide to the moral life of laity and married clergy. He finds that charity and labor were central. Moreover, redistribution of one' $s$ wealth to the needy and to the Church was not simply encouraged, but alms were "normally prescribed as means of salvation" $(1966: 80)$. However, Fedotov shows that despite the widespread representation of Christ as a beggar, in the Middle Ages "beggarliness or pious idleness is not the ideal," but rather "labor, especially manual labor, is invested with a religious value and is even set on the same level as monastic renunciation" $(1966: 78)$. In continuity with this tradition, contemporary Russian Orthodox theology usually insists simultaneously on the importance of charity and labor. The recent influential document The Basis of the Social Concept (Russian Orthodox Church 2000) gives char ity a prominent place in at least two chapters, "Labour and its fruits" and "Property." It emphasizes that the "Holy Scriptures point to the two moral motives of labour: work to sustain oneself without being a burden for others and work to give to the needy" (Russian Orthodox Church 2000). The question that logically appears then is: how to judge those who fail to sustain themselves and who become "a burden for others" ? The Basis does not provide an explicit solution to the obvious tension between the obligation to be charitable and the negative moral judgment bestowed upon those who openly rely on charity instead of labor. Official theology sets up a code but remains silent on this ethical question. Indiscriminate almsgiving by clergy and laity was part of everyday urban 
and rural Russian life for centuries. At important Orthodox feasts, services were held in churches, public celebrations and entertainment took place, and the poor, as well as vagrants and beggars were invited into people' $s$ homes for a meal and a handful of coins (Bernshtam 2005:282-286). Spontaneous, indiscriminate almsgiving to beggars was considered a worthy act and was widely practiced. At least until the second half of the 19th century, poverty was not defined as a social problem. In particular, those who renounced wealth for the sake of piety were approved, in contrast to tramps who begged in order to make a living (Golosenko 1996a and 1996b). 11 While holy fools occupy a special place in Russian Orthodoxy as ascetic characters (Fedotov 1966:317-343), they often arouse suspicion too. The mid-19th century ethnographer and historian Pryzhov (1996) denounces the duplicity of some holy fools who impudently hoarded wealth but exhibited poverty. Pryzhov locates the first repressive measures on begging in the 18th century as part of the modernization reforms under Peter the Great. The Emperor' $s$ efforts to replace chaotic almsgiving by organized, channeled charity were met with great resistance (1996:136). Pryzhov denounces almsgiving as being an "apparently pious" custom, but in fact "merciless and harmful" (1996:139). Many of Pryzhov' s contemporaries shared these views (Golosenko 1996a, 1996b). By the end of the 19th century, such ideas took a more defined shape and started to inform a new worldview: poverty and unemployment became categories of thought. Reforms were launched in order to respond to the increase of visible urban poverty aggravated by rapid migration from the countryside to industrial cities. Newly established work houses (doma trudoliubiia)-that

first emerged in St. Petersburg-tried to implement the idea that the able-bodied poor must be integrated into productive life and given a roof (Lindenmeyr 1986). These initiatives were inspired by earlier Western European reforms. However, in reality, the various types of such homes for the poor had very limited success.

Despite the political strength of the reform ideas, including those which introduced the categories of deserving and undeserving poor, traditional almsgiving to all kinds of beggars, deeply rooted in Orthodox ethics, remained the most popular expression of the Russian ethos of charity in late imperial Russia (Lindenmeyr 1990). One of the key characters of this new movement at the end of the 19th and the very beginning of the 20th century was Father Ioann of Kronstadt, a charismatic and influential Orthodox priest close to the Tsar' $s$ family. He created one of the first "homes of industry" and wrote about the emergence of poverty relief in Russia. Although he shared many of the reform ideas, he never renounced giving handouts to beggars (Lindenmeyr 1986, 1996; Kitsienko 2006).12 More generally, until the revolution of 1917, with the dramatic political and social changes it entailed, the powerful belief that "poverty is not a vice" remained untouched. This belief motivated traditional forms of almsgiving concurrent with the new ideas aiming at the transformation of the poor (Lindenmeyr 1996).

The town of Kronstadt, where Father Ioann served, is situated on an island in the Gulf of Finland, several kilometers outside of St. Petersburg. The pre-revolutionary priest was canonized by the Patriarchate of Moscow in 1990 as an all-Russian saint and became one of the most popular saints in the region of St. Petersburg. At my field site, located in the same region, I have on several occasions heard people, who acquired some knowledge 
about pre-1917 Orthodox debates on poverty, stating that Saint Ioann of Kronstadt would not give to such people-those active beggars who stand next to the church entrance nowadays-whom he called the "professional poor" (professional'nye nishchie). In fact, Father Ioann cont inued giving alms to all poor throughout his life. But these contemporary churchgoers prefer the work-oriented side of the charismatic priest' s philosophy. The historian Bronisław Geremek (1987) demonstrates that, in Christian Western Europe, the treatment of the poor, vagrants, and beggars from the Middle Ages onwards has always been permeated by a tension between repression and assistance, an idea exemplified in the title "La Potence ou la Pitié" ("gallows or pity"). Although punishment for begging and almsgiving was imposed later in Russia than in Western Europe, just like in the West, the strain between the two attitudes remained strong until the Bolshevik revolution, and it even seems that "pity" prevailed thanks to the endurance of religious tradition. Traditional Orthodox ethics of almsgiving resisted the attacks of Western-type ideas of transformation.

\section{Soviet and Early Post-Soviet Morals of Work}

Soviet ideology went much further than any imperial reform. In the new pattern, there was no place for religious charity and pity; work was a pivotal category in Soviet ideology. In this ideology, work became not only one moral category, but one of the supreme human virtues. "The possession of the virtue of work $\cdots$ was seen as the prerequisite for the rest of [the] positive human characteristics...The rest of the 'saintly character' of the Soviet ideal person was built around work" (Vladimirova 2006:120).13 Since the 1950s, the regime actively manipulated the category of work to repressive ends. The vocabulary of parasitism, strongly rooted in Russian colloquial talk since World War II, became particularly emphasized and anchored in law during the Khrushchev period in the 1950s and early 1960s, when special legislation against "parasites" was adopted (Fitzpatrick 2006). Following a well-established Soviet tradition to punish vagrants, beggars, and prostitutes, this legislation extended the scope to all "anti-social parasitical elements," including youth hanging around foreigners, those unwilling to work, those dressed in a Western way, people making a living from the informal economy, religiously active people (especially sectarians), even begging and petty-trading pensioners, and in several cases housewives who did not have an official job outside of the house. In addition, practicing one of the institutionally recognized forms of work was essential for gaining access to the social security system (McAuley 1979). The laws against parasitism condemned all those who strayed outside of what was defined as regular and socially-useful work as leftovers from capitalism who "impeded the Soviet march to communism" (Fitzpatrick 2006).

This teleological bias of the Soviet rhetoric disappeared with the crash of the regime. Nevertheless, much of the workings of the institutions of that time remained effective in institutional and popular definitions of worthy work (Rogers 2008), and in determining the categories of who deserves support (Yates 2004:240). While some local people refer to Saint Ioann of Kronstadt in order to legitimize the stigma they put on contemporary active beggars, many others use the far more widespread term of "parasites" (parazity). "Parasitism" continues to be the word for unworthy ways of earning money, motivated by laziness and immorality. Under the 
circumstances of early post-Soviet capitalism, the Soviet ideal of work as a central human virtue and its opposite, "parasitism," have informed social ethics. For example, in a post-Soviet-fashioned vocabulary, some churchgoers and clerics say that begging "is a business nowadays" (eto biznes seichas). The choice of the word biznes is not incidental. The term became widely used in colloquial speech in the post-Perestroika period to refer to non-physical work, most often commerce. (Using it in the context of begging means to ignore that begging is a physically demanding activity.) In the socialist period, labor was considered superior to commerce, especially commerce beyond the control of the state, having been associated with easy gain and cheating. "Making profits from marketing was illegal in most circumstances" and private trading activities were considered immoral (Humphrey and Mandel 2002:1). Today, the term biznes still often bears such a semantic nuance. Moreover, biznes has a strong connotation of calculation and profit seeking. Saying that "begging is a business now" means that beggars calculate and adjust their behavior in order to arouse compassion. While only sincere suffering and disability are considered deserving of compassion, the relatively young, able-bodied beggars automatically fall under suspicion of cheating. Although the clerics generally admit that the beggars really need money like everybody, they refuse to give to the able-bodied. This discrimination occurs while an entrepreneurial ethos of money-making within and outside of productive spheres has already gained legitimacy in Russian society (Patico 2009). Be it the phrase "professional poor" attributed to Saint Ioann of Kronstadt, the Soviet vocabulary of parasitism, or contemporary popular talk of begging as a biznes, the suspicion of a dishonest attempt to earn money, of inappropriate ways to use it-for vodka-and, more importantly, the accusation of immorality, is profoundly integrated in the everyday philosophy of clergymen. Whether they invoke theology, Soviet ideals, or post-Soviet-styled criticism of biznes, a certain idea of deservingness stemming from notions of work underlies their views. Work, then, appears as a human virtue incommensurable with the economic value that it would generate (Lambek 2008).

\section{Crafting Ethical Responses: Accepting While Rejecting}

Individual priests respond differently to the challenge that the very presence of beggars constitutes, but eventually they respond as a group with shared fundamental values. The idea of un-deservingness provides a common ground for the exclusion of active beggars. In reality, the clergymen support beggars and, as their politics of control upon the space inside and outside of the churches indicates, the priests want beggars to be part of church life. Unquestioned almsgiving may well belong to the pre-revolutionary and earlier past; however, the practice of almsgiving is still a vivid expression of charity. Instead of choosing between giving to the beggars and rejecting them, the priests reconcile the two. They create an object-centered choice between offering money or food, the kind of things that Rogers (2009) calls "materials of ethics." But the question is not simply about the things; it is also about the actions, like almsgiving, and about what the beggars could potentially do with the handouts.

Therefore, the dilemma between giving and refusing becomes a dilemma between what kind of things should be given and what potential actions could be undertaken with them. Graeber's (2001) theory of value stresses 
precisely this connectedness between things and actions. Drawing on his approach, it appears that a specific valuation procedure for things and actions underpins the priests' everyday ethics of almsgiving.

Although the collected amounts are small, the local priests consider the money to be detrimental for the undeserving beggars. While giving coins to all beggars is a popular practice today, the clergy and many of the most engaged churchgoers of the three local churches condemn the act of giving monetary alms to the able-bodied. There are, thus, two categories of alms money: the good monetary alms for "little old ladies" and the corrupting money given to younger panhandlers. These different moneys (Zelizer 1997) are directly defined by the moral portrait of their receivers. The priests, however, encourage donating food. The question about the appropriate type of handout for able-bodied beggars has been answered in the same way by all local priests regardless of their age or social background. The priests never speak of uncertainty in biblical interpretation; they do not look for a solution in the scriptures, although some of them have a favorite quotation from the Bible or a favorite saying with religious connotation. In private conversations and in sermons, they evoke the position of "the Holy Fathers of the Church," like that of Saint Ioann of Kronstadt, in order to justify the way they relate to begging. They prefer pragmatic solutions to meditative immersion in the scriptures. Those of the churchgoers and church workers, who strictly follow the priests, express the institutional justification of their practices in their church vernacular:

"The priest blessed (batiushka blagoslovil) giving them food, he didn' t bless giving them money." There are parishes where the beggars are sometimes invited to share meals at the table of the church (trapeza). This was not practiced by the parishes I studied-though food was occasionally brought to them outside. By blessing the gift of food, the priests encourage the reproduction of the traditional Orthodox practice and, at the same time, they continue to distinguish between deserving and undeserving poor through the content of their handouts.

The ethical competition between responding to the demand of the active beggar and penalizing him for his "faults" is solved by moving the focus from the act of giving-the moral value embodied in almsgiving remaining untouched-to the nature of the gift and its potentialities for future actions. Graeber (2001) emphasizes that the value of the objects is, in fact, the value of the actions that one can accomplish with them, and that economic and ethical values are interrelated. Indeed, in church almsgiving, the economic value of money is always considered in connection to the ethical value of the monetary transaction: What kind of relationship does money mediate? To what kind of social character is it passed on? The ethical valuation of alms money occurs in the larger context of a society in which able-bodied beggars are most often stigmatized as idle, suspected of playing needy, and abusing people' s compassion. The potential wider uses they could make of money fall under the same suspicion of abuses. Conversely, food can only be immediately consumed and there is little probability that one can exchange it for something else. In this way, when giving food, not only are the clerics accomplishing their Christian duty, but they also feel they are keeping the beggars' behavior under control. Thanks to this object-centered choice, the dilemma between giving and refusing has been neutralized, and the act of giving is no longer questioned. In the process, the priests index their thoughts and actions to different frames of historical and moral reference, a procedure 
constitutive of the elaboration of almsgiving as a simultaneous sanction and compassion. Through the ethical valuation that connects certain things to certain actions, they respond to the beggars and society. Thus, they go well beyond a self-centered project in which "people' s conduct is shaped by attempts to make of themselves a certain kind of person" (Laidlaw 2002:327), placing the others as their center of concern as much as themselves. These religious ethics are intrinsically relational, addressing a specific group and society at large.

\section{ACKNOWLEDGEMENTS}

Earlier versions of this article were presented in November 2008 at the annual meeting of the American Anthropological Association (San Francisco, USA) and in January 2009 at seminar titled "Socialist and Postsocialist Eurasia" held at the Max Planck Institute for Social Anthropology (Halle, Germany). I would

I ike to thank Melissa Caldwell, Jennifer Cash, Stephen Gudeman, Chris Hann, Patrick Heady, Nathan Light, Bea Vidacs, Vladislava Vladimirova, Anja Sing, and the members of the Max Planck Institute's seminar whose comments and suggestions inspired me in this version. I am very grateful to the three anonymous reviewers for their stimulating critiques and ideas. All shortcomings are, of course, mine.

\section{ENDNOTES}

1For the sake of anonymity, I do not name the city. With 80,000 inhabitants, this is the center of a district (munitsipal'nyi raion) of 220,000 inhabitants, the city included. It is neither economically successful, nor stricken by exceptional crisis, at least in comparison with other urban centers of the St. Petersburg region. 2 All names are pseudonyms.

3The Soviet surveillance of church attendance made it easier for elderly women to go to church and more difficult for men and younger women who were priority members of the Communist Party or of its branch for youth. In contrast to this situation, post-Soviet Russian Orthodoxy is clearly state-promoted. This connection between political power and Orthodoxy can at least partly explain why the churches became attractive places for men too. High attendance by middle-aged men and women is clearly a feature of contemporary urban Russian Orthodoxy.

4After the fall of the Soviet regime, popular Orthodox literature in the form of short books and pamphlets has played a crucial role for the promotion of Russian Orthodoxy (Benovska-Sabkova et al. 2010:19). 5 At the time of this interview, there were Central Asian Gypsy children, usually accompanied by one or two women, begging in the churchyard.

6 For the case of China, see Fernandez-Stembridge and Madsen (2002)

7I use "Gypsy" instead of "Roma" in order to focus on the perception that ethnic Russians have of them. For an extensive discussion of the two terms in the Russian context, see Lemon (2000).

8I use "vestibule" for the Russian term "pritvor" which, in the case of the churches, means a kind of airlock-a transitory space-between the big external door of the building and the inner door leading into the center of the ritual space.

9Residential schools are widespread in Russia. Following the Soviet educational tradition, they host children from problem families, or without parents, and tend to leave a durable negative mark on the social identity of their pupils.

10Kudriavtseva' s (2001) informants used the word "work" to describe their activity of begging. I have never come across such a term in the narratives and everyday speech of my informants.

11 Similar patterns of perception of beggars and tramps are prominent in Islam as well. For example, BellerHann (2008:152-164) shows that during the 19th and the first half of the 20th century, beggars among the Muslim Uyghur of Xinjiang were viewed as essentially religious characters; different forms of almsgiving were therefore considered conveying religious worth. At the same time, the people blamed cheating beggars who presented themselves as pious mendicants.

$12 \mathrm{By}$ the end of his life, the charismatic Father Ioann of Kronstadt, always surrounded by a miserable crowd begging for coins and food, accounts in one of his diaries how he was sinking into tiredness and anger over the unceasing flood of poor (Kitsienko 2006:177-179)

$13 \mathrm{Although}$ actual practices often widely differed from the ideology, the latter was profoundly incorporated into popular morality (Vladimirova 2006:126-134).

\section{REFERENCES}

Agadjanian, Alexander and Kathy Rousselet. 2010. "Individual and Collective Identities in Russian

Orthodoxy." In Chris Hann and Hermann Goltz, eds. Eastern Christians in Anthropological Perspective, 311-328. Berkley: University of Cal ifornia Press.

Beller-Hann, Ildiko. 2008. Community Matters in Xinjiang 1880-1949: Towards a Historical Anthropology of the Uyghur. Leiden and Boston: Brill.

Benovska-Sabkova, Milena, Tobias Kollner, Tunde Komaromi, Agata Ładykowska, Detelina Tocheva, and Jarrett Zigon. 2010. “' 'Spreading Grace' in Post-Soviet Russia.” Anthropology Today 26 (1) :16-21. Bernshtam, Tat' iana. 2005. Prikhodskaia Zhizn' Russkoi Derevni: Ocherki po Tserkovnoi Etnografii. St. Petersburg: Ethnographica Petropolitana/Peterburgskoe vostokovedenie.

Caldwell, Mel issa. 2004. Not by Bread Alone: Social Support in the New Russia. Berkeley: University of California Press.

2010. "The Russian Orthodox Church, the Provision of Social Welfare, and Changing Ethics of Benevolence." In Chris Hann and Hermann Goltz, eds. Eastern Christians in Anthropological 
Perspective, 329-350. Berkley: University of Cal ifornia Press

Fedotov, George P. 1966. The Russian Religious Mind. Vol. II The Middle Ages, the Thirteenth to the Fifteenth Centuries. Cambridge: Harvard University Press.

Fernandez-Stembridge, Leila and Richard P. Madsen. 2002. "Beggars in the Socialist Market Economy."

In Perry Link, Richard P. Madsen and Paul G. Pickowicz, eds. Popular China: Unofficial Culture and Globalizing Society, 207-230. Lanham: Rowman \& Littlefield Publishers.

Fitzpatrick, Sheila. 2006. "Social Parasites. How Tramps, Idle Youth, and Busy Entrepreneurs Impeded the Soviet March to Communism." Cahiers du Monde Russe 47 (1-2):377-408.

Geremek, Broni sław. 1987 [1978]. La Potence ou la Pitié. L'Europe et les Pauvres du Moyen Age à Nos

Jours. Paris: Gallimard.

Golosenko, Igor. 1996a. "Nishchenstvo Kak Sotsial” naia Problema." Sotsiologicheskie Issledovaniia $7: 27-35$.

1996b. "Nishchenstvo v Rossi i." Sotsiologicheskie Issledovaniia 8:18-25.

Graeber, David. 2001. Toward an Anthropological Theory of Value: The False Coin of Our Own Dreams.

New York: Palgrave.

Hojdestrand, Tova. 2005. "Needed by Nobody: Homelessness, Humiliation, and Humanness in Post-

Socialist Russia." Ph. D. Dissertation, Department of Social Anthropology, University of Stockholm.

Humphrey, Caroline and Ruth Mandel. 2002. "The Market in Everyday Life: Ethnographies of

Postsocialism." In Ruth Mandel and Humphrey Caroline, eds. Markets and Moralities: Ethnographies

of Postsocialism, 1-16. Oxford: Berg.

Kits i enko, Nadezhda. 2006. Sviatoi Nashego Vremeni: Otets loann Kronshtadtskii i Russkii Narod.

Moscow: Novoe Literaturnoe Obozrenie.

Kollner, Tobias. Forthcoming. "Built with Gold or Tears? Moral Discourses on Church Construction and the Role of Entrepreneurial Donations." In Jarrett Zigon, ed. Multiple Moralities and Religions in PostSoviet Russia. New York: Berghahn Books.

Kormina, Jeanne. 2010. “Avtobusniki: Russian Orthodox Pilgrims' Longing for Authenticity." In Chris Hann and Hermann Goltz, eds. Eastern Christians in Anthropological Perspective, 267-286. Berkeley: University of California Press.

Kudriavtseva, Maria. 2001. "Dramaturgi ia Poproshainichestva." In V. Voronkova, 0. Pachenkova, and E. Chikadze, eds. Nevidimye Grani Sotsial'noi Real'nosti, 37-49. St. Petersburg: Center for Independent Sociological Studies.

Ładykowska, Agata. Forthcoming. "Post-Soviet Orthodoxy in the Making: Strategies for Continuity Thinking Among Russian Middle-Aged School Teachers." In Jarrett Zigon, ed. Multiple Moralities and Religions in Post-Soviet Russia. New York: Berghahn Books.

Laidlaw, James. 2002. "For an Anthropology of Ethics and Freedom." Journal of the Royal Anthropological Institute (N. S. ) 8:311-332.

Lambek, Michael. 2000. "The Anthropology of Religion and the Quarrel between Poetry and Philosophy." Current Anthropology 41 (3) : 309-320. 2008. "Value and Virtue." Anthropological Theory 8 (2) :133-157.

Lemon, Ala ina. 2000. Between Two Fires: Gypsy Performance and Romani Memory from Pushkin to PostSocialism. Durham: Duke University Press.

Lindenmeyr, Adele. 1986. "Charity and the Problem of Unemployment: Industrial Homes in Late Imperial Russia." Russian Review 45 (1) :1-22.

1990. "The Ethos of Charity in Imperial Russia." Journal of Social History 23 (4):679-694. 1996. Poverty is Not a Vice: Charity, Society and the State in Imperial Russia. Pr inceton:

Princeton University Press.

Luehrmann, Sonja. 2005. "Recycling Cultural Construction: Desecularisation in Post-Soviet Mari-El." Religion, State and Society $33(1): 35-56$.

McAuley, Alastair. 1979. Economic Welfare in the Soviet Union: Poverty, Living Standards and Inequality.

Madison: University of Wisconsin Press.

Naletova, Inna. 2010. "Pilgrimages as Kenotic Communities Beyond the Walls of the Church." In Chris Hann \& Hermann Goltz, eds. Eastern Christians in Anthropological Perspective, 240-266. Berkeley: University of California Press.

Patico, Jennifer. 2009. "Spinning the Market: The Moral Alchemy of Everyday Talk in Postsocialist Russia." Critique of Anthropology 29 (2) :205-224.

Paxson, Margaret. 2005. Solovyovo: The Story of Memory in a Russian Village. Bloomington: Indiana

University Press.

Pryzhov, Ivan. 1996. 26 Moskovskikh Prorokov, lurodivykh, Dur i Durakov i Drugie Trudy po Russkoi Istori i Etnografii. St. Petersburg, Ezro, Moscow: Intrada.

Rogers, Douglas. 2008. “Old Believers between 'Society' and 'Culture' : Remaking Moral Communities and Inequalities on a Former State Farm." In Mark D. Steinberg and Catherine Wanner, eds. Religion, Morality, and Community in Post-Soviet Societies, 115-147. Washington, DC: Woodrow Wil son Center Press and Bloomington: Indiana University Press.

2009. The Old Faith and the Russian Land: A Historical Ethnography of Ethics in the Urals. Ithaca: Cornell University Press.

Sergazina, Ksenia. 2006. "Dinamika Vozrozhdenia Russkoi Religioznoi Kul' tury." In Kathy Rousselet and Alexander Agadjanian, eds. Religioznye Praktiki v Sovremennoi Rossii, 106-125. Moscow: Novoe izdatel' stvo.

Sibireva, Olga. 2009a. "Rural Orthodoxy. Parishes in Ryazan Oblast." Kultura 2:4-5 2009b. "Where Satan Still Lives: Orthodox Subculture in Russia." Kultura 2:10-15.

Stephenson, Svetlana. 1996. "0 Fenomene Bezdomnosti." Sotsiologicheskie Issledovaniia 8: 26-33. 2001. "The Abandoned Children of Russia-From 'privileged Class' to 'Underclass.' " In Stephen Webber and Ilkka Li ikanen, eds. Education and Civic Culture in Post-Communist Countries, 187-203. Houndmills: Palgrave.

Tarabukina, Arina. 2000. "Fol' klor i Kul' tura Pritserkovnogo Kruga." Ph. D. Dissertation, Department of Philosophy. Herzen State Pedagogical University of Russia, St. Petersburg. Accessed from http:// www. ruthenia. ru/folktee/CYBERSTOL/books/Tarabukina/arina_tarabukina. html on Jan 15, 2009. 
Russian Orthodox Church. 2000. The Basis of the Social Concept of the Russian Orthodox Church

Accessed from http://www. mospat. ru/en/documents/social-concepts/ on Dec 3, 2010.

Tikhonova, Natalia. 2003. Fenomen Gorodskoi Bednosti v Sovremennoi Rossii. Moscow: Letni i sad.

Vladimi rova, Vladis lava. 2006. Just Labor: Labor Ethic in a Post-Soviet Reindeer Herding Community.

Uppsala: Acta Universitatis Upsaliensis.

Wanner, Cather ine. 2007. Communities of the Converted: Ukrainians and Global Evangelism. Ithaca:

Cornell University Press.

Wanner, Catherine and Mark D. Steinberg. 2008. “Introduction: Reclaiming the Sacred after Communism."

In Mark D. Ste inberg and Cather ine Wanner, eds. Religion, Morality, and Community in Post-Soviet

Societies, 1-20. Washington, DC: Woodrow Wilson Center Press and Bloomington: Indiana University

Press.

Yates, Samantha Jane. 2004. "Living with Poverty in Post-Soviet Russia: Social Perspectives on Urban

Poverty." Ph.D. Dissertation, Department of Social Policy, London School of Economics and Political

Science.

Zelizer, Vivianna. 1997. The Social Meaning of Money: Pin Money, Paychecks, Poor Relief, and Other

Currencies. Princeton: Princeton University Press.

Zigon, Jarrett. 2008. "Aleksandra Vladimirovna: Moral Narratives of a Russian Orthodox Woman." In Mark

D. Ste inberg and Cather ine Wanner, eds. Religion, Morality, and Community in Post-Soviet Societies,

85-113. Washington, DC: Woodrow Wilson Center Press and Bloomington: Indiana University Press.

Leiden: Brill.

$$
\text { 2010. Making the New Post-Soviet Person: Moral Experience in Contemporary Moscow. }
$$

Zigon, Jarrett, ed. Forthcoming. Multiple Moralities and Religions in Post-Soviet Russia. New York:

Berghahn Books. 